\title{
Risk Factors in Oil and Gas Well Electronics Compared to Other Electronic Industries
}

\author{
S. Tiku ${ }^{3}$, A.F. Veneruso' ${ }^{1}$, R.K. Etchells ${ }^{2}$ and M. Pecht ${ }^{3}$ \\ 1 Schlumberger SRC, 14910 Airline Road, Rosharon - Texas 77583-1590 - USA \\ 2 Schlumberger, 200 Gillingham Lane, MD.4, Houston - Texas 77478 - USA \\ 3 CALCE Electronic Products and Systems Center, Engineering Laboratory Building, University of Maryland, College Park, MD 20742 - USA \\ e-mail: veneruso@rosharon.oilfield.slb.com - retchells@slb.com - stiku@calce.umd.edu - pech@eng.umd.edu
}

\begin{abstract}
Résumé - Facteurs de risques dans le secteur des équipements électroniques pour puits de pétrole et de gaz, comparés à d'autres industries électroniques — Le secteur des équipements électroniques pour puits de pétrole et de gaz est une industrie à faible volume, dans laquelle les temps de développement et d'exploitation des produits sont considérablement plus longs que ceux des composants commerciaux utilisés pour leur fabrication. Les systèmes électroniques utilisés, en particulier pour le contrôle permanent des puits de pétrole, doivent fonctionner de façon fiable durant toute la vie du puits. Cela impose des contraintes particulières pour l'électronique utilisée. La garantie de fiabilité dans un environnement sévère et pendant une vie plus longue nécessite des dessins, techniques de qualification et d'essai, et contrôles de qualité adaptés. Tous ces facteurs génèrent des risques considérables pour les fournisseurs et les producteurs d'équipements électroniques destinés aux puits de pétrole et de gaz.

Cet article présente une étude de ces facteurs de risques à prendre en compte dans la réalisation de produits destinés à la complétion et au contrôle continu de puits. Une comparaison avec d'autres industries électroniques à faible volume est présentée.
\end{abstract}

\begin{abstract}
Risk Factors in Oil and Gas Well Electronics Compared to Other Electronic Industries The oil and gas well electronics industry is a low volume industry in which the development and the operating life cycles of the electronic products used is considerably longer than those of the commonly available commercial parts used to build them. Oil and gas well electronic systems, especially the ones that are used for permanent monitoring of oil wells are required to function reliably at all times throughout the entire life of an oilwell. This gives rise to special requirements for the electronics used in this industry. Guaranteed reliability under high stress operating requirements over longer life cycle profiles necessitates the use of special design, qualification and testing techniques and quality controls. All these factors create considerable risks for the suppliers and manufacturers of oil and gas well electronics.

This paper presents a study of the factors that lead to risks, which manufacturers and suppliers of oil and gas well electronics must address while developing products for use in the well completion and continuous monitoring operations. A comparison with other low-volume electronic industries is provided.
\end{abstract}




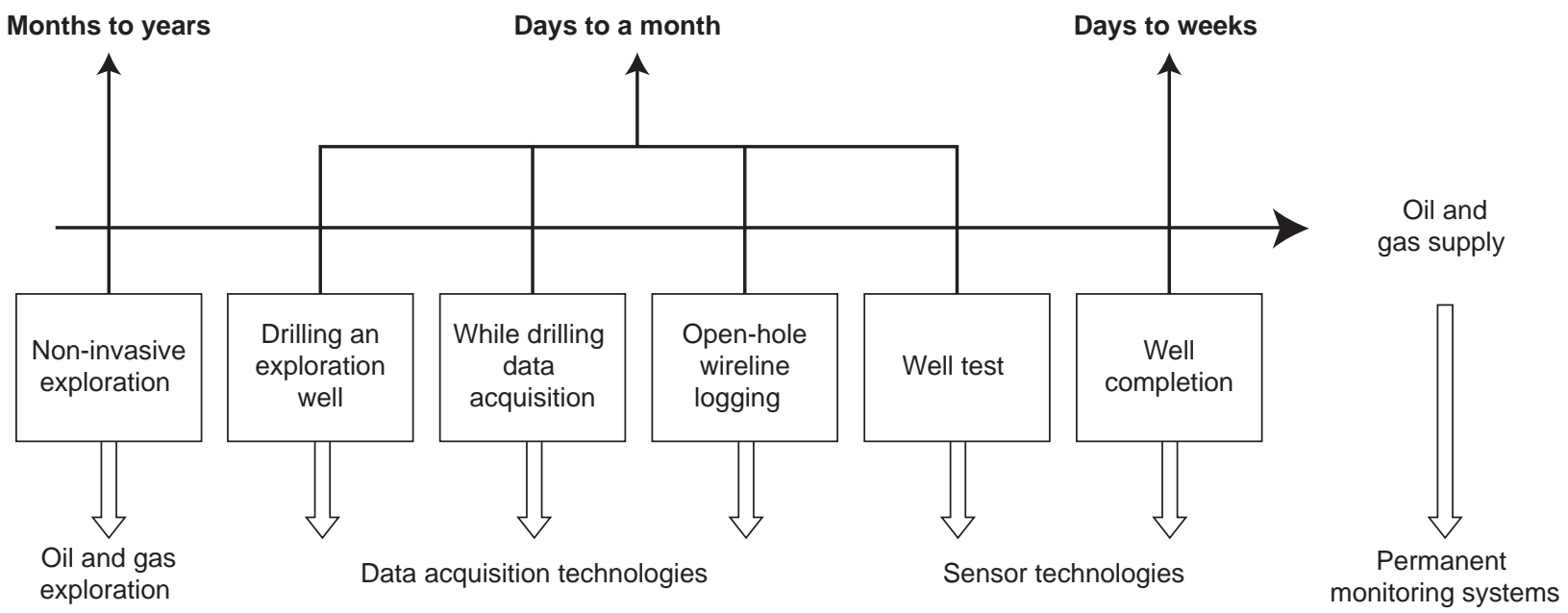

Figure 1

A time line of an oil and gas well showing the different stages from oil exploration to the final extraction from a well including the approximate time frames involved.

\section{OIL AND GAS EQUIPMENT ELECTRONICS}

Electronic products are essential in all aspects of oil and gas exploration, development and production, from the petroleum reservoir, to transport, and to the refinery, where it is transformed into fuels and other chemical products [1]. A hydrocarbon reservoir life-cycle chronologically consists of exploration, discovery, extended well test, appraisal, field development, production plateau, and production decline [2]. Figure 1 shows a time line for an oil and gas well depicting the use of electronic technologies.

The measurement of one or more physical quantities in or around the well is called well logging, with the word "log" used in the sense of a record. Well testing provides access to and measurement of dynamic reservoir data-including pressure, temperature, and fluid properties-while the well is either flowing or shut in. Well completion is the work conducted on a wellbore to establish safe production of the resource (i.e., oil and gas) after the production casing string ${ }^{1}$ has been set. Based on the operations along the time line, the four major applications of electronic products in the oil and gas industry are:

- Oil and gas exploration: Electronic technologies are used extensively in turning untapped resources into recoverable reserves by acquiring an understanding of the architecture and fluid flow behavior of the reservoir. Initial geologic information from seismic surveys, well-logs, productivity tests, and other remote sensing techniques such as gravimetric, radiometric and electromagnetic sensing, are used

1 A long section of connected pipe that is lowered into a wellbore and cemented to provide strength for installation of wellhead equipment, to seal off leaky, low strength or fractured formations, and to seal off high-pressure zones so that lower pressure formations may be drilled with lower drilling fluid densities [3]. to evaluate reservoir boundaries, estimate reserves, plan drilling programs, and design surface facilities.

- Data acquisition technologies: Data acquisition technologies compile and integrate the reservoir data including geologic, seismic, well log, well test, pressure, rock, fluid and interpretative data. Data interpretation, geological modeling, reservoir simulation and production analysis help to create field depletion scenarios and reservoir development strategies [2]. These are used to find how much oil or gas is there, how much is recoverable, how fast it can be recovered, how much capital expenditure is required, and what will be the return on investment [4].

- Sensor technologies: Sensors are used to identify the reservoir rock and any fluids contained therein by measuring their physical properties. The physical properties used are resistivity (oil has high resistivity, salt water has low resistivity), radioactivity (gamma ray detector), acoustic impedance, pressure, density, temperature and temperature gradient. Measurement of these properties enables the improvement of oilwell effectiveness.

- Permanent monitoring and control systems: Permanent monitoring systems measure and record well performance and reservoir behavior in real time, $24 \mathrm{~h}$ a day, throughout the lifetime of the reservoir. This information can be used by engineers to dynamically manage hydrocarbon assets, to update reservoir models, to optimize production techniques, and diagnose problems so that remedial treatments and field development strategies can be refined or adjusted [1].

Permanent downhole gauge (PDG) systems are widely used for horizontal and multi-lateral wells, as an alternative to wireline conveyed downhole surveys used traditionally for vertical wells [5]. Gauges collect data useful for both shortterm troubleshooting and long-term development planning. Downhole measurements include temperature, pressure, 
resistivity, acoustics, density, flow, sand detection, scale or paraffin deposition rates and corrosion rates [2].

The benefits of permanent downhole monitoring systems include the reduction of operational hazards, remote acquisition and analysis of data, transient analysis of problems with minimum or no wireline intervention, optimization of injection rates, elimination of sand production, verification and adjustment of reservoir models, improved estimation of reserves, and maximization of individual well production [1].

In most oil and gas applications, specialized electronic products have to provide precision measurements worthy of a physics laboratory, while operating in environments typically beyond those associated with the most rugged military equipment. The operating environments range from desert to arctic temperatures, and from atmospheric pressure land surveying to deep sea-bed pressures for surveying offshore prospects. In addition, the equipment has to be operated inside hightemperature, and high-pressure oil and gas reservoirs.

Electronics is recognized as one of the main causes of failure of permanent downhole measurement and control systems [5]. The need to transport and operate these electronics in a variety of hostile environmental conditions means packaging these systems to withstand challenging levels of temperature, mechanical shock and vibration, humidity, sand, salt water spray, and water immersion. Manufacturing such equipment requires meeting stringent operational and life cycle requirements, and demonstrating regulatory compliance. A delineation of these factors leading to risks for the manufacturers can pave the way to understand the means to tackle them.

\section{RISK FACTORS}

Engineering is a balancing act of tradeoffs and compromises among conflicting and sometimes mutually exclusive goals. An engineer's job is to drive developing methods and technologies into new areas, combining past experience with present science to create future products and innovations [6]. During the development of any product, risks associated with its use should be identified and quantified at the engineering design stage itself. This can help designers to create a design that is risk-informed. Risk, in this context, is the probability of occurrence of an unwanted event due to the use of the product [7].

The oil and gas industry is riddled with risk and uncertainty at almost every stage of business from exploration through production to downstream marketing. This industry needs to minimize costs, produce oil and gas efficiently with minimum damage to oil well formations and acquire information to improve the drilling operation and to enhance reservoir drainage during production. As the current economic climate is forcing oil companies to focus sharply on their core business, they are relying more on their suppliers and sub-contractors to share the risks.
The conventional risk and uncertainty models used in the oil industry deal with wellbores and reservoirs, but similar models can be used to explore the impact of unconventional risks due to political, legal, environmental, health or other issues for the equipment used during exploration and extraction [7]. To frame a model for these unconventional risks, the intangibles for each of these risks need to be understood and defined. Properly assessing risk for any operation provides a competitive advantage for a company. For the oil and gas industry, a miscalculation on this account can lead to unwanted upstream decisions like abandonment of facilities, and cost implications associated with any environmental or safety related measures.

The specific applications of electronic products in the oil and gas industry set special conditions and constraints on products as well as on the customers who use them. The decision on whether to supply such products depends on how the risks associated with these factors can be handled to ensure the profitability of the enterprise as well as to maintain confidence in the end product. Table 1 provides a comparison of the needs of various low volume electronics industries, which include the oil and gas well electronics industry. The factors leading to risks that can affect the continued supply of electronic parts for the oil and gas industry are detailed below.

\subsection{Production Volume and Cost}

Yearly production is defined as the total number of a product built for an industry in a year. High volume production enables a company to "optimize" manufacturing processes and costs. Generally the availability of parts and spares is ensured due to the volumes. On the other hand, low volume production can lead to challenges in terms of part availability, and effective manufacturing processes.

The total market for electronic products used in oil well applications is limited. There are only about 3000 drilling rigs in operation worldwide. A comparison of yearly production for the oil electronic industry with some other low volume industries is given in Table 1.

Oil and gas electronic products do not have the benefits of scale economies. ${ }^{2}$ They demand a large capital investment because of intensive technical and logistical efforts for specialized design, materials and parts selection, manufacturing processes, quality assurance and reliability. In addition, there are costs to cover regulatory requirements, insurance, and services and equipment required to manage liabilities and manufacturer risks. All of these costs must then be distributed only over a small number of products, leading to high costs for an individual product.

2 Most personal computers (PCs) are produced in such large quantities that the final price to the user actually drops below the off-the-shelf price of the individual chips, connectors and other hardware. 
TABLE 1

Comparison of key characteristics of different industries

\begin{tabular}{|c|c|c|c|c|c|c|c|}
\hline & $\begin{array}{l}\text { Oil and Gas } \\
\text { completions }\end{array}$ & $\begin{array}{c}\text { Communication } \\
\text { Satellites }\end{array}$ & $\begin{array}{l}\text { Automotive } \\
\text { electronics }\end{array}$ & Avionics & $\begin{array}{c}\text { Defense } \\
\text { electronics }\end{array}$ & $\begin{array}{c}\text { Space } \\
\text { electronics }\end{array}$ & $\begin{array}{c}\text { Medical } \\
\text { electronics }\end{array}$ \\
\hline $\begin{array}{l}\text { Units } \\
\text { produced } \\
\text { in a year }\end{array}$ & $\begin{array}{l}\text { Hundreds } \\
\text { of gauges, } \\
\text { tens of valves }\end{array}$ & Tens & $45 \mathrm{M}$ & $100-1000$ & Hundreds & $\begin{array}{l}8 \text { space shuttles } \\
\text { in } 2 \text { decades }\end{array}$ & $\begin{array}{l}\text { Diagnostics: } \\
\text { thousands } \\
\text { Implants: } \\
\text { hundreds }\end{array}$ \\
\hline $\begin{array}{l}\text { Environment } \\
\text { of operation }\end{array}$ & $\begin{array}{l}20000 \mathrm{psi}, \\
-40 \text { to } 150^{\circ} \mathrm{C}, \\
\text { corrosive wellbore } \\
\text { fluids }\end{array}$ & $\begin{array}{l}\text { Vacuum, radiation } \\
-156 \text { to } 121^{\circ} \mathrm{C}\end{array}$ & $\begin{array}{l}-40 \text { to } 85^{\circ} \mathrm{C}, \\
\text { vibration, dust, } \\
\text { water, road salt }\end{array}$ & $\begin{array}{l}\text { Vacuum, } \\
\text { radiation, } \\
-65 \text { to } 90^{\circ} \mathrm{C}, \\
\text { vibration }\end{array}$ & $\begin{array}{l}\text { Dust, salt water, } \\
\text { radiation, } \\
-55 \text { to } 125^{\circ} \mathrm{C}\end{array}$ & $\begin{array}{l}\text { Vacuum, radiation, } \\
-156 \text { to } 121^{\circ} \mathrm{C}\end{array}$ & $\begin{array}{l}\text { Body fluids, } \\
\text { disinfecting } \\
\text { chemicals }\end{array}$ \\
\hline $\begin{array}{l}\text { Average } \\
\text { operating } \\
\text { h/y }\end{array}$ & $\begin{array}{l}\text { 24/7/365 systems: } \\
8766 \text { h/y/system }\end{array}$ & $\begin{array}{l}\text { 24/7/365 systems: } \\
8766 \text { h/y/system }\end{array}$ & $\begin{array}{l}\text { Up to } 780 \text { (trucks) } \\
550 \text { (cars) h/y/ } \\
\text { automobile }\end{array}$ & $\sim 4500 \mathrm{~h} / \mathrm{y} /$ plane & $\begin{array}{l}\text { AWACS }{ }^{1} \text { systems: } \\
\text { 24/7/365 systems } \\
\text { Assault systems: } \\
\text { usage may vary } \\
\text { from peace } \\
\text { to war conditions }\end{array}$ & $\begin{array}{l}2 \text { flights } \\
\text { of } 4-17 d / y\end{array}$ & $\begin{array}{l}\text { Only implants } \\
\text { are } 24 / 7 / 365 \\
\text { systems }\end{array}$ \\
\hline $\begin{array}{l}\text { Cost } \\
\text { per system }\end{array}$ & $\begin{array}{l}\text { US\$150 } 000 \\
\text { (gauge system, } \\
\text { well pressure } \\
\text { monitoring) } \\
\sim \text { US } \$ 250,000 \\
\text { (valve system) } \\
\sim \text { US } \$ 1-2 \mathrm{M} \\
\text { (smart completion) }\end{array}$ & US\$10 M & US\$12 000-65000 & US\$15-50 M & $\begin{array}{l}\text { US\$500 M } \\
\text { (tanks) } \\
\sim \text { US\$40-200 M } \\
\text { (fighter aircraft) } \\
\sim \text { US\$2-4 B } \\
\text { (submarines) }\end{array}$ & $\sim \mathrm{US} \$ 2-4 \mathrm{G}$ & $\begin{array}{l}\text { US\$50 000- } \\
100000\end{array}$ \\
\hline $\begin{array}{l}\text { Usage } \\
\text { lifetime }\end{array}$ & $5-10 y$ & $3-6 y$ & $\begin{array}{l}10 \mathrm{y}, \\
\text { or } 100000 \text { miles } \\
\text { (for cars) } \\
150000 \text { miles } \\
\text { (for trucks) }\end{array}$ & $20-30 y$ & $\begin{array}{l}8-16 \text { y } \\
\text { (tanks) } \\
20-30 y \\
\text { (fighter aircraft) } \\
15-20 y \\
\text { (submarines) }\end{array}$ & $20-30 \mathrm{y}$ & $5-10 y$ \\
\hline $\begin{array}{l}\text { Level of } \\
\text { operator } \\
\text { training } \\
\text { required }\end{array}$ & Medium & High & Low & High & High & Very high & $\begin{array}{l}\text { Very high } \\
\text { for surgical } \\
\text { intervention; } \\
\text { high for } \\
\text { diagnostics; } \\
\text { medium } \\
\text { for monitoring }\end{array}$ \\
\hline $\begin{array}{l}\text { Consequences } \\
\text { of failure }\end{array}$ & $\begin{array}{l}\text { Gauges fail: } \\
\text { well data lost } \\
\text { Valves fail: } \\
\text { oil or gas } \\
\text { production lost }\end{array}$ & $\begin{array}{l}\text { Data and/or } \\
\text { communications } \\
\text { lost } \\
\text { High on flight } \\
\text { critical systems }\end{array}$ & $\begin{array}{l}\text { Miltiple human } \\
\text { lives at risk for } \\
\text { braking or steering } \\
\text { failure } \\
\text { Lost time and } \\
\text { money for power } \\
\text { train and other } \\
\text { failures }\end{array}$ & $\begin{array}{l}\text { Multiple human } \\
\text { lives at risks for } \\
\text { flight, } \\
\text { navigation, } \\
\text { or environment } \\
\text { system failure } \\
\\
\text { Lost time and } \\
\text { money for } \\
\text { unscheduled } \\
\text { repairs }\end{array}$ & $\begin{array}{l}\text { Huge number } \\
\text { of lives at risk } \\
\text { for failure } \\
\text { of national security } \\
\text { critical systems }\end{array}$ & $\begin{array}{l}\text { Multiple human } \\
\text { lives at risk on } \\
\text { manned missions } \\
\text { Property loss } \\
\text { and/or loss } \\
\text { of scientific } \\
\text { data otherwise }\end{array}$ & $\begin{array}{l}\text { Individual human } \\
\text { life at risk or pain } \\
\text { and suffering } \\
\text { Higher medical } \\
\text { costs }\end{array}$ \\
\hline $\begin{array}{l}\text { In-service } \\
\text { health } \\
\text { monitoring, } \\
\text { diagnostics } \\
\text { and } \\
\text { maintenance }\end{array}$ & $\begin{array}{l}\text { Medium: time } \\
\text { consuming and } \\
\text { costly } \\
\text { No maintenance } \\
\text { possible on } \\
\text { permanent } \\
\text { equipment }\end{array}$ & $\begin{array}{l}\text { Very high } \\
\text { (built-in test) }\end{array}$ & High (indicators) & $\begin{array}{l}\text { Very high } \\
\text { maintenance } \\
\text { (lots of } \\
\text { indicators and } \\
\text { built-in tests) }\end{array}$ & $\begin{array}{l}\text { Very high } \\
\text { maintenance } \\
\text { (lots of } \\
\text { indicators and } \\
\text { built-in tests) }\end{array}$ & $\begin{array}{l}\text { Maintenance } \\
\text { difficult during } \\
\text { operation } \\
\text { (lots of built-in } \\
\text { sensors) }\end{array}$ & $\begin{array}{l}\text { Diagnostics: } \\
\text { possible } \\
\text { Implants: } \\
\text { possible }\end{array}$ \\
\hline $\begin{array}{l}\text { Whether } \\
\text { repairable }\end{array}$ & $\begin{array}{l}\text { Impractical: } \\
\text { time consuming } \\
\text { and costly }\end{array}$ & $\begin{array}{l}\text { Impractical } \\
\text { time consuming } \\
\text { and costly }\end{array}$ & Yes & $\begin{array}{l}\text { Yes, but with } \\
\text { obsolescence } \\
\text { problems }\end{array}$ & $\begin{array}{l}\text { Yes, but affected } \\
\text { by obsolescence } \\
\text { of some } \\
\text { components }\end{array}$ & $\begin{array}{l}\text { Yes, but very } \\
\text { costly }\end{array}$ & $\begin{array}{l}\text { Useful only } \\
\text { for diagnostic } \\
\text { equipment }\end{array}$ \\
\hline $\begin{array}{l}\text { Development } \\
\text { cycle time }\end{array}$ & $2-4 y$ & $2-4 y$ & $2-3 y$ & $\begin{array}{l}2-4 \mathrm{y} \\
\text { (commercial) } \\
8-10 y \\
\text { (fighter) } \\
3-5 y \\
\text { transport }\end{array}$ & $4-8$ y & $2-3 y$ & $1-3 y$ \\
\hline
\end{tabular}




\subsection{Life Cycle Issues and Parts Procurement}

The design, development, production and application life cycle of oil electronic products is generally much longer than those of volume-driven products and significantly longer than the life cycles of parts that comprise these products. Oil electronic products typically require 2-4 y for design and certification and have service lives of 5-10 y. As a result, several parts may have to be customized for special types of wellheads, and for such custom-built equipment, the lead times and costs may be high [1].

It may not be possible to find suppliers who are willing to manufacture and supply specialized parts for oil electronic equipment. The small volume of parts used and liability issues related to the oil industry are factors that make many parts suppliers reluctant to support the oil industry. As a result, many part manufacturers have withdrawn from the oil electronics market and many of the older parts have been discontinued. Consequently, oil and gas well electronics manufacturers have been forced to use commercial-off-the-shelf $(\mathrm{COTS})^{3}$ parts or parts from supply chains dedicated to other products. Even if some willing suppliers are found, continued part availability becomes a critical factor for sustainment.

3 Commercial-off-the shelf (COTS) parts refer to "components that are available from manufacturers` catalogs or through distribution channels - regardless of specifications" [8].
Figure 2 illustrates the typical supply chain for oil and gas well electronics. For the oil electronic industry, managing this supply-chain is important to maintain production and reduce downtime. Reliance of oil sector industries on parts from supply chains dedicated to other products is called "cross-vertical product integration", which leads to risks.

Technological risks from a cross-vertical supply-chain typically arise from the inability of the product to meet design functions over its lifecycle or from difficulties in manufacturing consistently to high quality standards, leading to problems of quality, reliability, and safety. Business risks from a crossvertical supply-chain arise from shifts in the supply and demand balances in the marketplace, affecting the cost, marketability and availability of the product, and the profit margins [9].

\subsection{Manufacturing Yield, Quality Control and Traceability}

Manufacturing success is often measured by yield, which is the ratio of the number of usable products that pass quality control tests, to the number of potentially usable products before the tests [10]. Achieving a high manufacturing yield of electronic products used in the oil industry is difficult, since products have tight tolerances. Lowering the severity of quality testing may improve yield in the short term, but it may give rise to undesirable reliability implications during product use.

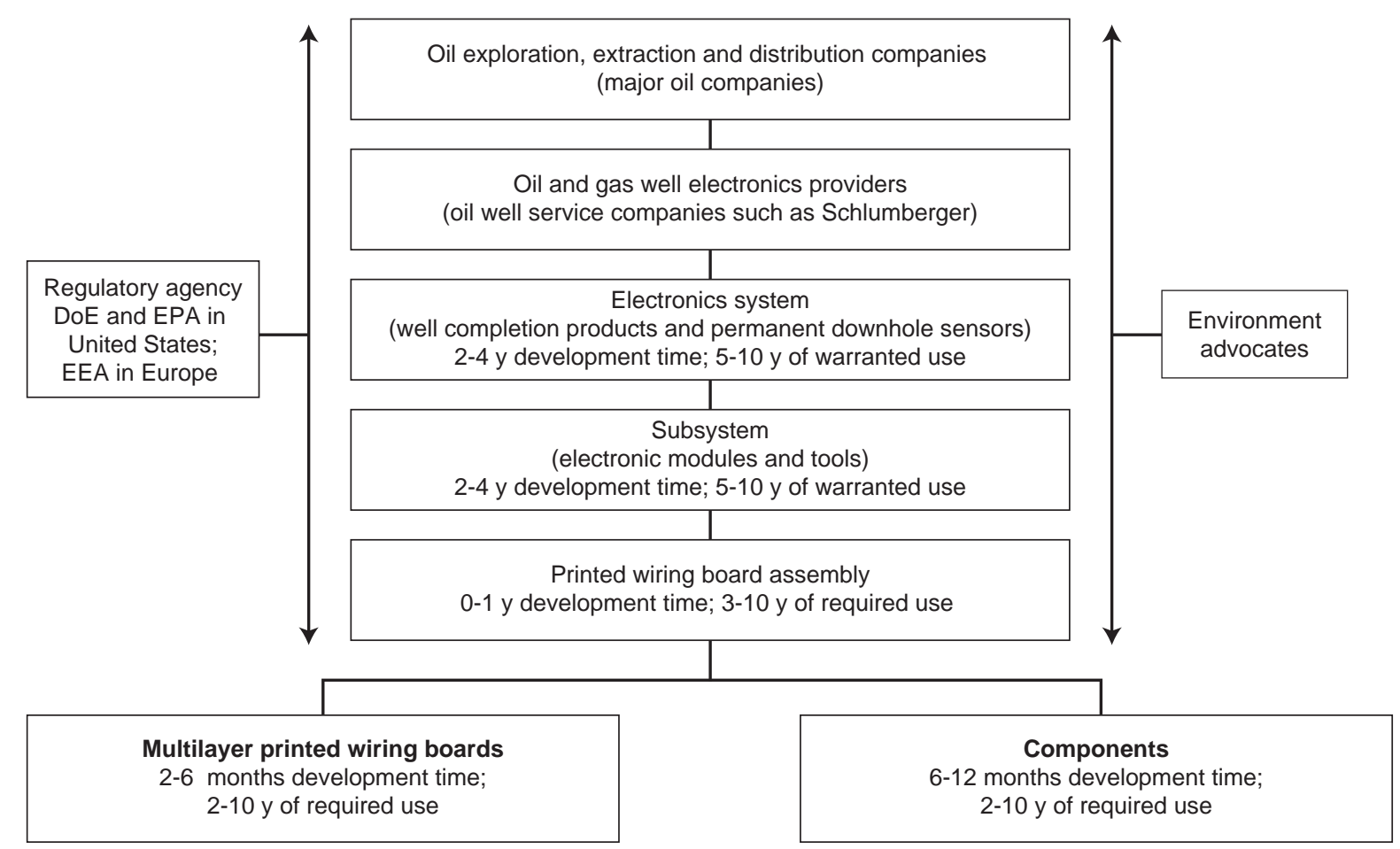

Figure 2

Oil and gas well electronics supply chain. 
Quality is defined as "conformance to specified requirements agreed with the client" [11]. Quality can be achieved by a robust and repeatable manufacturing process and reduction of performance variabilities in the final product. The benefits of quality control include cost avoidance and increased customer satisfaction [9]. Effective quality control can lead to profitability over the long term, can help in maintaining a lead over competition, and most importantly, can help manufacturers stay in business.

Quality is important for oil electronics manufacturers since there are costs associated with it. Costs associated with quality include failure costs, quality appraisal costs and failure prevention costs. The cost of quality reduces as quality control and quality assurance are progressively introduced in a manufacturing system. This requires control over variances such as rework and cost overruns. Moreover, the quality team, along with associated engineers, must carry out functions such as design review and qualification, pre-production planning, pre-service planning, and process qualification and validation to reduce costs.

Traceability is a process to track parts and products. Traceability is a means to enable the end users as well as the manufacturers to track a product to its more basic materials, manufacturing or assembly steps, and to identify and isolate problems. Traceability is also useful for reordering parts and materials if obsolescence becomes an issue. In general, all products should be traceable to all receiving, production, delivery and installation stages [12].

\subsection{Environment of Operation}

Volume-driven electronic products, such as desktop computers and consumer electronics generally operate in benign conditions. However, the typical downhole environment for oil and gas well completions is composed of briny, corrosive borehole fluids with temperatures ranging over $150^{\circ} \mathrm{C}$, and bottomhole pressures ranging up to 20000 psi. Furthermore, the operational stresses of power dissipation, shock, vibration, current and voltage are often substantially greater for electronics used in the oil and gas industry. These environmental conditions affect the selection of components, materials, and testing conditions.

To assess the level of risk, a product life cycle environment profile including details about the assembly, storage, handling, maintenance and scenario for the use of the product must be developed along with the expected severity and duration of these environments. This profile provides the necessary inputs for failure assessment. Since, life cycle loads can cause strength degradation in materials (e.g., combined loads can accelerate damage and reduce the fatigue limit), the life cycle environment should be used for the development of design guidelines, assembly guidelines, qualification and specification processes, parts selection and management, quality assurance, product safety, warranty and support commitments, and regulatory conformance.
High temperature is a significant factor affecting the performance and reliability of oil and gas well electronics [13]. Both during oil and gas exploration and production, temperatures as high as $200^{\circ} \mathrm{C}$ can be expected. To continue to have the advantage of state-of-art computation, memory and power systems, there is a need to develop electronic technologies that can withstand high temperatures over extended periods of time.

Oil electronics manufacturers may not be able to find parts that satisfy their temperature range requirements. In this case, some parts may have to be used beyond their rated temperature values, utilizing "uprating". Uprating is a process to assess the ability of a part to meet the functionality and performance requirements of the applications in which the part is used beyond the manufacturers' specifications [14]. Many of the commercially available parts may not be appropriate for use in the oil and gas well environments, or their reliability may be significantly decreased with extended use in such environments. The packaging used for parts, the printed circuit board material, and the plating materials on traces may also affected by high temperatures, pressure and corrosive fluids, or shock and vibration.

\subsection{Continuous Operation, Reliability and Stability}

Intelligent completions of oil wells involve the electronic monitoring and controlling of downhole sensors, gauges, and valves. Precious data is lost, is any of these malfunction. If the control system for valves fails, it can mean production loss. Since a typical offshore platform-drilling rig costs more than US $\$ 150000$ to operate per day, the economic consequences of a failure can be enormous in terms of lost rig time. Moreover, if the valves fail at a high flow rate, sand particles can damage the well and erode the pipe.

Today oil and gas exploration is venturing into remote areas and water depths approaching $10000 \mathrm{ft}$. with expectation of limited or no intervention. Continuous monitoring using electronic equipment is essential to maintain a regular flow of oil from these wells. Many electronic products used in oilwell monitoring systems operate 24 hours, 7 days a week for 365 days a year. Once installed, it is cumbersome to maintain them as long as they remain downhole. Recovering and repairing a part is time consuming and costly and also results in downtime. Also, the productive life of an oil and gas well may be 10 years or more, so permanent downhole equipment must last that long to satisfy requirements [4].

Permanent downhole equipment must be reliable and stable at the same time. Reliability is the ability of a part or product to perform as intended (i.e., without failure and within specified performance limits) for a specified time, in its life cycle application environment [15]. Stability refers to the drift in the actual values obtained from the measuring devices, and is crucial since variation in the measurement with time should be attributable to an actual change rather 
than an uncharacterized drift [4]. Both reliability and stability can be difficult to achieve in downhole electronic products because of long life cycles under harsh application environments [9]. For example, field track records reported for the period 1995-2001 showed that five-year reliability of permanent gauge installations was $90 \%$ for temperatures lower than $100^{\circ} \mathrm{C}$, but only about $50 \%$ in wells where temperature went up to $150^{\circ} \mathrm{C}[16]$.

Reliability enhancement through design and use of extensive assurance methods is essential to reduce the risk of equipment failure and unsafe operation. Designers must rely on proven quantitative designs, validation tools and virtual qualification techniques for this purpose. One of the design approaches to meet the reliability specifications is to include redundant components. However, redundant components occupy valuable space, and consume precious power, and there is a possibility of common mode failures ${ }^{4}$ affecting reliability.

Reliability for electronic products used in permanent monitoring systems can be assured through reliability analysis, by using virtual qualification techniques, and through testing. Virtual qualification techniques can be used to evaluate the possible damage to the product through its life cycle from manufacture to operation, including storage and transportation. These techniques can provide an estimate of the life expectancy of the product under the stresses encountered. The types of tests that can be conducted for reliability assurance include screening, pre-production testing or reliability qualification testing (RQT). Screens can be used to weed out early life failures occurring due to manufacturing, material, and other variabilities. Pre-production testing can be used to ensure the reliability of production hardware that may be affected due to changes in tooling, workflow, design, or other factors. RQT refers to a set of environmental and functional tests performed on electronics equipment to demonstrate its reliability before it is installed in a well.

\subsection{Human Safety and Environmental Considerations}

Hydrocarbon production and petrochemical processing plants have inherent economic, human safety and environmental risks. In the worst disaster of its kind, on July 6, 1988, 167 people perished on the Piper Alpha platform in the icy North Sea. US\$1 B platform was lost, along with up to $10 \%$ of the United Kingdom's oil production capability. The insurance payment from Lloyd's of London, which covered the value of the platform, lost production, and the US\$700 000 paid to every victim, among other items, totaled a record US $\$ 2.8 \mathrm{~B}$, almost twice the second highest payment for a single event, besides a natural disaster such as a strong hurricane.

4 Failure that can affect a set of functionally identical components or systems as a direct result of common or shared root cause.
The human safety impact was also demonstrated in a June 19, 1991, article in the New York Times, detailing that 14 US petrochemical disasters in 1987-1991 resulted in 7 dead, 138 injured and a cost of $\$ 246 \mathrm{M}$. Both these pieces of data illustrate the huge financial, human and business fallout potential of a petrochemical operation turning into a disaster.

Safety has always been a consideration in oilfield operations. However, over the past decade or so, enhanced safety is seen not only as desirable, but also beneficial to business [17]. To achieve this, each component installed in petrochemical operations need to be thoroughly vetted for safety considerations. The new safety era also requires collaboration between customer and supplier at the outset to identify responsibilities and duties of both parties. This requires that the electronics suppliers state and demonstrate safety policies for their products, and establish procedures for periodic review of safety management systems for their products.

One of the tools to demonstrate safety in operation is quantitative risk assessment (QRA). QRA uses numerical techniques to calculate the risk of specific hazards during operation of a piece of electronic equipment in terms of probable frequency of occurrence, and consequences for integrity of the installation and human safety. Quantification of the risk is followed by remedial action based on the classification of the risk in three groups. In the first group, the risk is acceptably high, and should be avoided. In the second group, risk is so low that no mitigation is required. In the third group in between these two, there is a trade-off between the level of risk and the cost of remediation [17].

Another method which can be used during product development to reduce the probability of failures and its adverse consequences is Failure Modes Mechanisms and Effects Analysis (FMMEA). FMMEA is a systematic approach to identify potential failure mechanisms and associated failure models from all potential failures modes and then to prioritize them to identify critical failure mechanisms and associated failure models. In contrast to the traditional FMEA practices, FMMEA can help the design team to evaluate the time-to-failure due to specific failure mechanisms, which is a key metric for reliability assessment of any product.

\subsection{Regulations and Liability}

Conforming to government regulations, standards and directives is a necessity for the manufacturers and the customers of oil electronics. Some of these standards are healthbased, some are aesthetic, but they all raise scientific questions about the types and rates of emissions, contributions of different sources of emissions, synthetic versus biogenic sources, atmospheric chemistry, and the influence on terrain and meteorology. Some unique issues include air quality impact, treatment and disposal of naturally occurring radioactive material, and the wastewater stream generated from oil and gas exploration and production [18]. 
In the past, environmental decisions were based on the technologies available at the time and the costs involved. This approach failed to take into account the unique nature of risks for each production facility, and resulted in wastage of time, money and effort. It has been realized that a reassessment of the risks associated with a regulation helps to redefine the regulation in conformance with the technology and its usage. For example, regulations originally designed for tanks that stored light oil required that oil storage tanks be fitted with costly scrubbers to prevent the emission of volatiles. However, this regulation was found to be inappropriate for the large number of tanks that store heavy oil with less volatile material. This consideration led to the development of new test methods for properly estimating the amount and type of reactive gases emitted from oil tanks, and consequently to a review of regulatory requirements based on scientific data thus obtained [18].

In the electronics industry, there are many examples that depict the influence of risks arising from development of new legislations. For example, there is a massive effort towards developing lead-free parts and products, primarily driven by European regulations rooted in the environmental and health risks of lead usage. Some of the risks associated with this transition include the cost and availability of lead-free technologies, unresolved technical issues associated with the lead-free solder processing, long-term reliability of lead-free assemblies, and managing traceability of lead-free parts in the supply chain [19].

Liability is associated with reliability, safety, lifecycle and the environment of operation. Failure of the parts used in an oilwell product can lead to liability problems for the manufacturer. Environmental and human harm could lead to expensive lawsuits. Manufacturers must always consider liability costs when designing and maintaining oil and gas well electronic products.

\subsection{Intellectual Property and Information Security Services}

Intellectual property (IP) very broadly means the legal rights relating to intellectual activity in the industrial, scientific, literary and artistic fields [20]. Generally speaking, intellectual property law aims at safeguarding creators and other producers of intellectual goods and services by granting them certain time-limited rights to control the use made of these productions. A manufacturer producing custom-made proprietary electronic systems for an oil industry user may exert IP rights over the technology and the use of the product. In many cases the individual service companies patent inventions to keep their competitors from using their developments. They may also choose not to patent but to keep the technology as trade secret, so that they do not have to divulge or share that technology outside of the company.
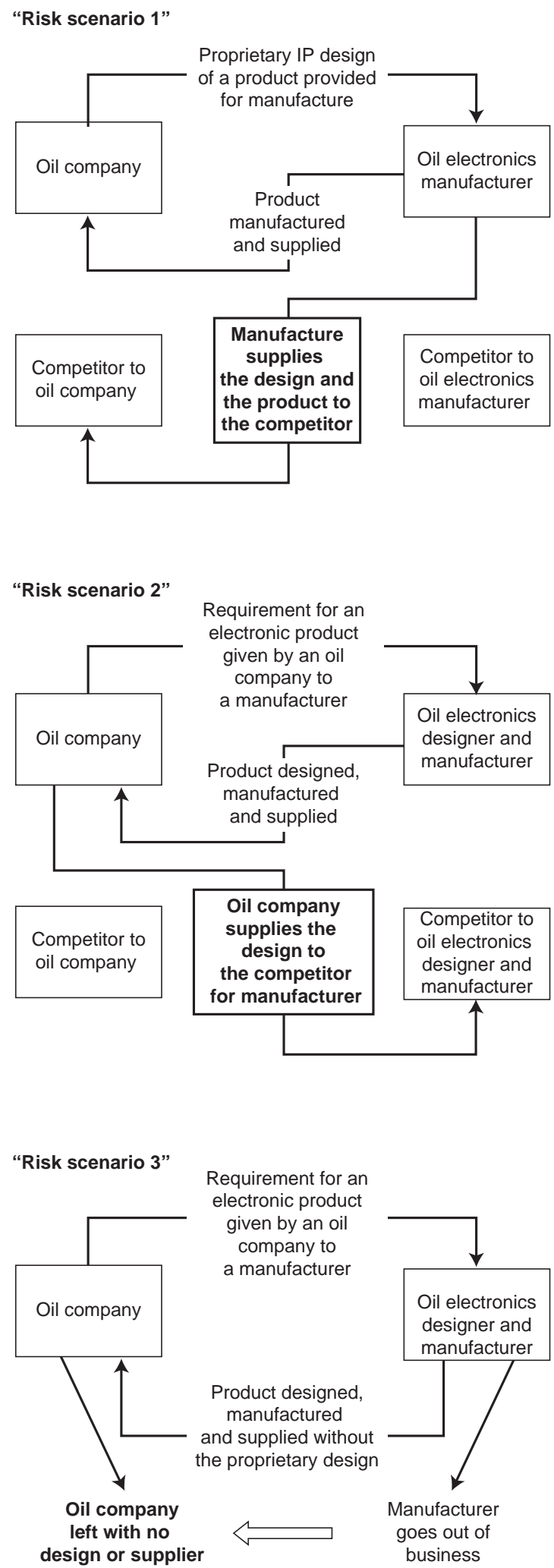

Figure 3

Intellectual property risk scenarios associated with manufacturing and supplying oil electronics. 
Intellectual property becomes a risk factor when a customer purchases from a supplier who is not willing to share the IP rights. Moreover, the secrecy of the individual service companies prevents any collaboration that could lead to improved technologies or speed up technology development. Various scenarios in which IP becomes a risk factor are depicted in Figure 3.

Security of sensitive information pertaining to processes and electronic systems is also a concern for oil and gas well electronics. It is necessary to develop an active approach to security protection in order to guard vital information infrastructures [21].

\section{CONCLUSIONS}

Manufacturing and supplying electronics to be used in oil and gas well exploration, data acquisition, calculating well effectiveness, and permanent monitoring systems involves taking risks. Understanding the factors leading to these risks paves the way for handling the risks in design, manufacture, supply and use.

Many aspects of oil and gas industry electronics are remarkably similar to those for communication satellites. Commercial communication satellites, like oil and gas well equipment, are difficult to fabricate, difficult to deploy and generally inaccessible for repair, replacement or recovery. In both cases, once the systems are installed it is not practical to retrieve them for maintenance or postmortem analysis. The costs of the products are high due to the low volume in which they are produced and failure often implies a significant loss. It is also not practical to test and qualify new equipment over the entire expected period of operation before installing it, because the intended longevity of the product is typically 5 years or more. Therefore analytical and accelerated testing techniques are essential in the development of these systems to ensure their reliable operation over a long lifetime.

Risk management activities should be used throughout the product lifecycle for oil and gas well electronics. A FMMEA can be conducted during the design phase to identify potential failure mechanisms, and associated times-to-failure. Design changes can be initiated to avoid potential failures. Design marginality tests like HALT can be conducted to further explore design deficiencies.

A structured part selection and management methodology, which incorporates an "eyes-on, hands-off" approach, is a useful risk management tool during product development [2224]. Part availability, part cost, part manufacturer quality, distributor quality, part performance, part reliability, assembly and life cycle obsolescence comprise the factors to be assessed. Reliability capability evaluation of prospective suppliers [25] can also be used during procurement to measure the electronics manufacturers' ability to identify and understand their reliability related objectives and the effectiveness of the reliability processes and practices. Once product design is complete, accelerated testing can be used to get actual reliability data on oil electronics products. Health monitoring and remaining life estimation techniques can be used during operation to further reduce the possibility of failures.

In summary, in the current electronics market, availability of parts suitable for use in specialized low-volume applications, like oil electronics, is continually reducing. For continued availability of electronics parts and modules, suppliers need to remain aware of production volume, parts procurement issues, manufacturing yield, traceability, environment and duration of operation, reliability and stability, human safety issues, environmental issues, regulations, liability issues, intellectual property issues, and lifecycle costs.

\section{ACKNOWLEDGEMENTS}

The encouragement and support of this project by $B P$ 's Upstream Technology Group, Houston, Texas, under the leadership of Mr. Brock Williams, is gratefully acknowledged. The project was part of the Reliable Electronic Permanent Monitoring assignment conducted by the Schlumberger Reservoir Completion Center, Rosharon, Texas.

\section{REFERENCES}

1 Baker, A. et al. (1995) Permanent Monitoring - Looking at Lifetime Reservoir Dynamics. Oilfield Review, 7, 4, 32-56.

2 Beamer, A. et al. (1998) From Pore to Pipeline, Field-Scale Solutions. Oilfield Review, 10, 2, 2-19.

3 Schmumberger, Oilfield Glossary, Retrieved on September 1, 2004 from http://www.glossary.oilfield.slb.com/

4 Eck, J. et al. (1999) Downhole Monitoring: The Story So Far. Oilfield Review, 20-33.

5 Den Boer, J.J. (1999) The Use of High Temperature Electronics in Downhole Applications. HITEN Conference in Berlin, 149-152.

6 Colwell, B. (Jan 2002) Phrenology, Astrology, Risk, and Product Quality. Computer, 35, 1, 12-14.

7 Bailey, W., Couet, B., Lamb, F., Simpson, G., and Rose, P. (2000) Taking a Calculated Risk. Oilfield Review, 12, 3, 2035.

8 Rhea, J. (1999) Custom components: Surviving in a COTS World. Military \& Aerospace Electronics, 10, 7.

9 Magrab, E. et al. (1997) Perspectives to Understand Risks in the Electronic Industry. IEEE Transaction on Components Packaging and Manufacturing Technology, Part A, 20, 4, 542-547.

10 Ferris-Prabhu, A.V. (1992) Introduction to Semiconductor Device Yield Modeling, Boston, MA, Artech House.

11 Burnett, N. et al. (1993) Quality. Oilfield Review, 5, 3, 46-59.

12 Jackson, M., Mathur, A., Pecht, M. and Kendall, R. (1999) Part Manufacturer Assessment Process. Quality and Reliability Engineering International, 15, 457-468.

13 Pecht, M., Lall, P., and, Hakim, E. (1997) Influence of Temperature on Microelectronics and System Reliability: A Physics of Failure, CRC Press, New York.

14 Das, D., Pendse, N., Wilkinson and C. Pecht, M., (2001) Parameter Recharacterization: A Method of Thermal 
Uprating. IEEE Transactions on Components and Packaging Technologies, 24, 4, 729-737.

15 Pecht, M.G., Das, D., and Ramakrishnan, A. (2002) The IEEE Standards on Reliability Program and Reliability Prediction Methods for Electronic Equipment. Microelectronic Reliability, 42, 1259-1266.

16 Veneruso, A.F., Kosmala, A.G., Bhavsar, R., Bernard, L.J., and Pecht, M. (2001) Engineered Reliability for Intelligent Well Systems. Offshore Technology Conference, OTC 13031.

17 Hansen, H., Myers, S., Redd, E., and Shannon, R. (1993) Pursuing the Case for Safety. Oilfield Review, 5, 3, 36-45.

18 Office of Natural Gas and Petroleum Technology, Oil \& Gas Environmental Research \& Analysis Program, Retrieved on Septemberber 1, 2004 from

http://www.fossil.energy.gov/programs/oilgas/publications/ programplans/1999/6envi.pdf

19 Ciocci, R. and Pecht, M. (2004) Questions Concerning the Migration to Lead-free Solder. Circuit World, 30, 2, 34-40.

20 International Bureau of WIPO, WIPO's Development Cooperation Activities, WIPO/CNR/ABU/93/9.
21 Heejin., J., and Sangwood, K.(2000) A Self-Extension Monitoring for Security Management. Computer Security Applications, ACSAC 16th Annual Conference, 196-203.

22 Jackson, M., Sandborn, P., Pecht, M., Davis, C.M. and Audette, P. (1999) A Risk-Informed Methodology for Parts Selection and Management. Quality and Reliability Engineering International, 15, 261-271.

23 Syrus, T, Pecht, M., and Humphrey, D. (2001) Part Assessment Guidelines and Criteria for Parts Selection and Management. IEEE Transactions on Electronics Packaging Manufacturing, 24, 4, 339-350.

24 Syrus, T, Pecht, M., and Uppalapati, R. (2001) Manufacturer Assessment Procedure and Criteria for Parts Selection and Management. IEEE Transactions on Electronics Packaging Manufacturing, 24, 4, 351-358.

25 Tiku, S. and Pecht M. (2003) Auditing the Reliability Capability of Electronics Manufacturers. Proceedings of ASME International Electronic Packaging Technical Conference and Exhibition, Maui, Hawaii, USA.

Final manuscript received in November 2004 or distributed for profit or commercial advantage and that copies bear this notice and the full citation on the first page. Copyrights for components of this work owned by others than IFP must be honored. Abstracting with credit is permitted. To copy otherwise, to republish, to post on servers, or to redistribute to lists, requires prior specific permission and/or a fee: Request permission from Documentation, Institut français du pétrole, fax. +33147527078 , or revueogst@ifp.fr. 